Pustaka Karya: Jurnal Ilmiah Ilmu Perpustakaan dan Informasi Vol. 8 No. 1, Juni 2020, Hal. 45-52

http://dx.doi.org/10.18592/pk.v7i15.3759

ISSN (p) : 2089-5216 | ISSN (e) : 2723-7699

\title{
Profesi arsiparis sebagai sumber daya manusia dalam mengelola arsip statis ${ }^{1}$ Wahfiuddin Rahmad Harahap \\ ${ }^{1}$ Program Studi Ilmu Perpustakaan dan Informasi UIN Raden Fatah Palembang \\ ${ }^{1}$ Jl.Prof. K. H. Zainal Abidin Fikri No.KM. 3, RW.5, Pahlawan, Kec. Kemuning, Kota Palembang, \\ Sumatera Selatan 30126 \\ Email: ${ }^{1}$ wahfiuddin31@gmail.com
}

\begin{abstract}
The purpose of writing this scientific article is to provide a conceptual and theoretical description of human resources in a static archive management system using the literature review method obtained from various trusted sources. Having knowledge and skills in managing static archives through educational programs and archival training will enhance the ability of archivists as human resources for managing archives in archival institutions. This is because archivists are the most important asset in managing information in the form of static archives in the archive institution. Increasing the professionalism of archival human resources must be carried out through archival training and guidance.
\end{abstract}

Keywords: archivist; human resources; profession; static archives

\begin{abstract}
ABSTRAK
Tujuan penulisan artikel ilmiah ini adalah untuk memberikan deskripsi konseptual dan teoritis tentang sumber daya manusia dalam sistem manajemen arsip statis dengan menggunakan metode kajian literatur yang didapat dari berbagai sumber terpercaya. Memiliki pengetahuan dan keterampilan dalam mengelola arsip statis melalui program pendidikan dan pelatihan arsip akan meningkatkan kemampuan arsiparis sebagai sumber daya manusia pengelola arsip di lembaga arsip. Hal ini dikarenakan arsiparis adalah aset yang paling penting dalam mengelola informasi berupa arsip statis di lembaga arsip. Peningkatan profesionalitas sumber daya manusia arsip harus dilakukan melalui pelatihan dan bimbingan arsip.
\end{abstract}

Kata Kunci: arsiparis; arsip statis; profesi; sumber daya manusia

\section{PENDAHULUAN}

Pengelolaan arsip atau manajemen arsip memerlukan sistem yang dapat menjamin arsip dapat disediakan dan disajikan dengan cepat, tepat, lengkap dan aman untuk mendukung kelancaran proses manajemen dan administrasi. Hal ini nantinya diharapkan dapat menjadi sarana yang menjamin terselamatkannya dan lestarinya arsip untuk kepentingan penelitian, pengembangan ilmu pengetahuan dan teknologi serta memori individu dan lembaga sebagai bagian dari memori kolektif bangsa.

Dalam pengelolaan arsip diperlukan Sumber Daya Manusia (selanjutnya disingkat dengan SDM) kearsipan atau arsiparis yang memiliki pengetahuan dan ketrampilan yang tepat. Peran arsiparis sebagai tenaga profesional yang terlatih dengan pendidikan awal dan berkelanjutan dalam melayani masyarakat pengguna dengan mendukung proses penciptaan, pemilihan, pemeliharaan arsip dan membuatnya tersedia untuk dimanfaatkan (Kistanto, 2014: 2.27). Selain itu manajemen arsip merupakan tanggungjawab bersama antar seluruh anggota masyarakat, administrator dan 
pembuat keputusan, pemilik atau pihak yang menyimpan arsip publik atau pribadi dan juga tanggungjawab arsiparis serta spesialis pengelola informasi lainnya. SDM yakni tenaga profesional yang terlatih merupakan salah satu sumber daya yang harus dialokasikan dengan baik guna mendukung manajemen arsip secara tepat.

Arsip harus dikelola oleh SDM yang mampu menjalankan fungsi-fungsi dan layanan organisasi, baik fungsi administrasi, edukasi, penelitian, preservasi maupun fungsi-fungsi pembinaan. SDM dipandang sebagai kekuatan terbesar dan aset intelektual (intelectual capital) yang harus dikembangkan sehingga potensinya dapat menjadi keunggulan kompetitif bagi organisasi. Pengembangan SDM secara berkelanjutan mutlak diperlukan untuk meningkatkan pengelola arsip dan pengembangan lembaga kearsipan. Profesionalitas SDM kearsipan mengacu pada kemampuan dan pengalaman pendidikan dan pelatihan yang akan menentukan kualitas pelaksanaan fungsi dan tujuan yang diharapkan

\section{TINJAUAN PUSTAKA}

Profesi merupakan kelompok lapangan kerja yang khusus melaksanakan kegiatan/ pekerjaan yang memerlukan keterampilan dan kehlian tinggi guna memenuhi kebutuan yang rumit dari manusia, didalamnya pemakaian dengan cara yang benar akan keterampilan dan keahlian tinggi hanya dapat dicapai dengan dimilikinya penguasaan pengetahuan dengan ruang lingkup yang luas, mencakup sifat manusia, kecenderungan sejarah, dan lingkungan hidupnya serta adanya disiplin etika yang dikembangkan dan diterapkan oleh kelompok anggota yang menyandang profesi tersebut (Suwarno, 2010: 100).

Menggaris bawahi gagasan bahwa arsiparis sebagai profesi dikaitkan dengan defenisi di atas tentu kita harus menyetujuinya. Karena suatu hal yang dikatakan "profesi” haruslah melalui pendidikan formal sehingga memiliki pengetahuan yang khusus serta keterampilan yang mumpuni. Seseorang tidaklah langsung bisa dikatakan arsiparis jika ia tidak melalui pendidikan formal dan memiliki pengetahuan dibidangnya. Hal ini dikarenakan arsiparis adalah suatu profesi dalam hal pekerjaan.

Seseorang bisa melakukan pekerjaan memotong rumput, karena pekerjaan tersebut tidak memerlukan ilmu dalam mengerjakannya. Oleh karenanya pekerjaan sebagai pemotong rumput tidak bisa dikategorikan sebagai profesi. Profesi hanya akan diperoleh jika melalui tiga kriteria profesi sebagai berikut (Istiana, 2014: 74) 1) merupakan pekerjaan yang memerlukan persyaratan intelektual berupa penguasaan ilmu pengetahuan tertentu 2) pekerjaan itu ditujukan untuk orang lain/ berorientasi pada jasa 3) keberhasilan pekerjaan diukur dari seberapa jauh para pemakai jasa terpenuhi kebutuhannya, dengan kata lain berorientasi kepada kepentingan masyarakat pengguna.

Lembaga arsip merupakan salah satu unit kerja yang memberikan jasa layanan kepada penggunanya. Kearsipan berperan sebagai ilmu pengetahuan dan sebagai ilmu terapan. Sebagai ilmu pengetahuan karena secara umum telah memenuhi syarat-syarat yaitu dapat dipelajari, mempunyai metodologi dan memenuhi persyaratan lainnya. Sedangkan sebagai ilmu terapan, karena memang pertama kali dikembangkan kearsipan sebagai sesuatu yang bersifat aplikatif yang pada mulanya diterapkan di sektor dunia usaha/ bisnis dan kemudian menyebar pada organisasi pemerintahan yang belakangan ini berkembang dengan sangat pesat (Sumrahyadi Dan Widyarsono, 2014: 1).

Untuk mencapai taraf profesinal, profesi arsiparis perlu memiliki syarat seperti kompetensi, kepribadian dan kecakapan. Posisi kompetensi menjadi sangat sangat penting dalam melakukan 
segala bentuk kearsipan. Sehingga arsiparis dapat mengelola arsip dan memberikan pelayanan kepada penggunanya dengan baik sesuai dengan standar operasionalnya.

\section{METODE PENELITIAN}

Metode penelitian kualitatif deskriptif dan studi literatur digunakan dalam penelitian ini. Menurut Bogdan dan Taylor (dalam Moleong; 2004) mendifisikan pendekatan kualitatif sebagai prosedur penelitian untuk menghasilkan data deskriptif yaitu berupa kata-kata tertulis ataupun lisan dari orang-orang (informan) dan perilaku yang diamati. Dengan menggunakan metode kualitatif hasil penelitian ini dapat menginterpretasikan data yang diperoleh peneliti dari lapangan.

Metode deskriptif adalah prosedur pemecahan masalah yang diselidiki dengan menggambarkan keadaan subjek/objek penelitian (Nawawi; 1993). Melalui pendekatan ini diharapkan mampu memberikan jawaban lebih dalam yang menyeluruh, bukan hanya bersifat permukaan dan pembuktian teori semata, sesuai dengan tujuan penelitian yang ingin dicapai. Penelitian ini akan menguak lebih dalam secata teoriritis dan konseptual tentang arsiparis sebagai sebuah profesi.

Studi literatur digunakan sebagai teknik untuk mengumpulkan data-data yang diperlukan mulai dari buku, jurnal, artikel, majalah, serta referensi karya ilmiah lainnya yang berkaitan dengan tema yang diangkat. Terdapat 3 tahapan dalam proses pengumpulan data yaitu editing untuk memeriksa kembali data yang sudah didapatkan. Lalu organizing berupaya mengelola data yang sudah didapatkan. Dan terakhir yaitu finding dilakukan agar analisis terhadap hasil pengelolaan data mampu berjalan sampai kepada tahap penarikan simpulan.

\section{HASIL DAN PEMBAHASAN}

\section{A. SDM KEARSIPAN SEBAGAI PENGELOLA ARSIP STATIS}

Kennedy dan Schauder menjelaskan setidaknya terdapat tiga kategori SDM kearsipan sebagai pelaksana program kearsipan, yakni tenaga profesional, tenaga para-profesional dan tenaga klerikal. Sebagaimana diketahui, di dunia internasional tenaga profesional pengelola arsip terdiri dari dua profesi yang berbeda yakni records manager (manajer rekod) sebagai pengelola arsip dinamis dan arsiparis yang ahli dalam mengelola arsi statis (Kennedy, 1998: 15).

Acland menyebutkan bahwa manajer rekod adalah orang yang terdidik secara profesional, terlatih dan berpengalaman, serta bertanggungjawab dalam menjalankan layanan manajemen arsip dinamis secara efektif dan efisien guna memenuhi kebutuhan organisasi (Acland, Glenda, 1993: 477-464.). Mengenai arsiparis Acland menyatakan bahwa arsiparis adalah seseorang yang terdidik secara profesional, terlatih dan berpengalaman, serta bertanggungjawab dalam pengelolaan atau administrasi arsip statis dengan melakukan kegiatan penilaian dan mengidentifikasi arsip yang memiliki nilai berkelanjutan, mendokumentasikan dan melestarikan arsip sesuai dengan konteksnya dengan mengupayakan dan memfasilitasi penggunaannya secara berkesinambungan.

Keputusan Menpan No. PER/3/M.PAN/3/2009 pasal 3 menyebutkan tugas pokok arsiparis adalah melaksanakan kegiatan pengelolaan arsip dan pembinaan kearsipan yang meliputi ketatalaksanaan kearsipan, pembuatan petunjuk kearsipan, pengolahan arsip, penyimpanan arsip, konservasi arsip, layanan kearsipan, publikasi kearsipan, pengkajian dan pengembangan kearsipan, serta pembinaan dan pengawasan kearsipan.

SAA Guidelines for College and University Archive secara khusus misalnya menjelaskan mengenai tenaga profesional kearsipan di lembaga kearsipan perguruan tinggi dengan 
menguraikan standar profesional berikut untuk merefleksikan deskripsi posisi, persyaratan pendidikan dan kepercayaan ilmiah mengenai kriteria SDM yang diperlukan, yakni (Society Of American Archivists (Saa), 1999).

\section{Tenaga profesional}

Yang merupakan tenaga arsiparis profesional dengan surat mandat seperti sertifikat keahlian. Arsiparis sebagai direktur harus merupakan tenaga tetap yang memiliki ketrampilan manajemen yang kuat, dapat berinteraksi secara efektif dengan bagian administrasi, fakultas, mahasiswa, alumni dan masyarakat umum. Ia harus berada dalam struktur administrasi yang memberikan kewenangan untuk melakasanakan misi program. Staf profesional lain mencakup arsiparis, profesional di bidang terkait seperti preservasi, ilmu perpustakaan, manajemen arsip dinamis atau disiplin akademis lainnya.

\section{Staf pendukung}

Yakni tenaga semi profesional atau non-akademis yang bertugas memberikan layanan referensi, layanan teknis dan administratif, yang diharapkan juga memiliki keterampilan teknologi dan organisasi. Selain itu diperlukan juga staf lainnya yang merupakan staf tetap maupun staf paruh waktu seperti 1) staf profesional sebagai asisten arsiparis yang dapat melaksanakan tugas penilaian, layanan umum atau referensi, pemberkasan dan deskripsi, preservasi dan tanggung jawab program pengembangan lainnya; 2) staf pendukung teknis yang bertugas menyiapkan akuisisi arsip dan sarana akses untuk kegiatan administrasi dan layanan referensi; 3) petugas ruang baca yang memiliki keterampilan interpersonal untuk layanan umum;

4) staf administrasi yang bertangungjawab pada aktivitas operasional termasuk manajemen kantor, korespondensi, penataan arsip administrasi dan tugas-tugas lainnya, yang didukung oleh keahlian teknis termasuk pengolahan kata dan manajemen pangkalan data; 5) mahasiswa magang yang bekerja mendukung program di bawah pengawasan staf dalam melakukan temu kembali, penataan arsip atau pengelolaan materi yang tidak sensitif, serta mendukung akses arsip melalui penggunaan teknologi; 6) tenaga sukarelawan yang bekerja dengan pengawasan yang memadai antara lain dalam tugas resepsionis, membantu pengolahan arsip, membantu kegiatan teknis, mengarahkan aktivitas pameran, dan sebagainya; 7) staf yang dilatih dalam program pelatihan profesional untuk memberikan layanan kearsipan, tugas teknis, dan layanan umum.

\section{B. PENGEMBANGAN PROFESIONALISTAS SDM KEARSIPAN}

Pelatihan berguna untuk memberikan penyegaran pengetahuan tentang kebijakan dan praktekpraktek kearsipan. Profesionalitas bersama dengan kompetensi dapat diperoleh melalui pendidikan formal dan/ atau pendidikan dan pelatihan kearsipan. Profesionalitas selalu dikaitkan dengan efisiensi dan keberhasilan, menjadi sumber bagi peningkatan produksi, pertumbuhan, kemakmuran dan kesejahteraan, baik dari individu pemilik profesi maupun masyarakat lingkungannya.

Mengenai profesionalitas, Pamungkas yang dikutip oleh Dwi mengemukakan bahwa manusia profesional dianggap sebagai manusia berkualitas yang memiliki keahlian serta kemampuan mengekspresikan keahliannya itu bagi kepuasan orang lain dan mempunyai nilai tambah yang tinggi. Ekspresi keahlian tersebut tampak dalam perilaku analisa dan keputusan-keputusannya (Nurmaningsih, 2009: 112). 
Shepherd menyatakan bahwa profesi pengelola arsip, sebagaimana halnya kelompok profesional lainnya, membutuhkan suatu dasar pengetahuan dari teori dan teknik intelektual yang melandasi keahlian khususnya (Shepherd, Elizabeth, 2006: 10). Ia juga mengutip pendapat Wilensky bahwa kegiatan profesional bersifat teknis dan didasari pada pengetahuan dan pelatihan sistematis. Sayangnya, di tanah air diketahui setidaknya di lembaga kearsipan daerah baru sebagian pimpinannya yang telah mengikuti diklat kearsipan, dan pada umumnya berasal dari mutasi pejabat unit-unit lainnya yang tidak berkaitan dengan bidang kearsipan, artinya pendidikan formalnya pun tidak secara langsung berkaitan dengan bidang ini. Bahkan yang sangat disayangkan juga adalah sebagian besar arsiparisnya juga belum mengikuti diklat kearsipan, khususnya karena mereka merupakan produk impassing, bukan melalui diklat penciptaan arsiparis.

Dedi yang dikutip oleh Bambang dalam artikelnya berjudul “Arsiparis sebagai Profesi dan Standar Kompetensinya (Menguak Konsep Jabatan Fungsional Arsiparis)” menyatakan bahwa: profesi menunjuk pada suatu jabatan atau pekerjaan yang menuntut keahlian, tanggungjawab dan kesetiaan pada profesi (Iwan, 2009: 32). Suatu profesi secara teori tidak bisa dilakukan oleh sembarang orang yang tidak dilatih atau disiapkan untuk itu. Sementara profesional menunjuk pada dua hal yaitu penampilan atau kinerja seseorang yang sesuai dengan tuntutan profesinya, serta menunjuk pada orang yang melakukan pekerjaan tersebut. Profesionalisme menuntut tiga prinsip utama yakni memperoleh pendidikan yang cukup, mendapatkan pelatihan yang memadai dan menerima gaji yang memadai.

Selanjutnya dalam artikel tersebut disebutkan pula karakteristik suatu profesi. Pertama, profesi memiliki fungsi dan signifikansi sosial bagi masyarakat. Kedua, profesi menuntut keahlian tertentu yang diperoleh melalui proses pendidikan dan pelatihan yang memadai, yang dilakukan oleh lembaga pendidikan yang akuntabel. Ketiga, profesi didukung oleh suatu disiplin ilmu tertentu atau pengetahuan yang sistematis. Keempat, ada kode etik yang dijadikan sebagai suatu pedoman perilaku anggota beserta sangsi yang jelas dan tegas terhadap pelangaran kode etik. Pengawasan terhadap penegakan kode etik tersebut dilakukan oleh organisasi profesi yang bersangkutan. Kelima, sebagai konsekuensi dari layanan dan prestasi yang diberikan kepada masyarakat maka anggota profesi secara perorangan atau kelompok memperoleh imbalan finansial atau material. Kelima karakteristik tersebut dapat diterapkan pada pekerjaan kearsipan atau arsiparis meskipun ada beberapa karakteristik yang belum terpenuhi secara maksimal.

Sebagai contoh, arsiparis memiliki fungsi memberikan layanan sumber informasi dan signifikansi sosial bagi masyarakat. Arsiparis harus memiliki kompetensi yang tinggi melalui pendidikan dan pelatihan yang akuntabel dalam disiplin ilmu- ilmu kearsipan. Untuk karakteristik kode etik dan penegakan kode etik di Indonesia relatif belum berjalan. Imbalan finansial/ material bagi pengelola arsip juga belum memadai dan relatif kecil dibandingkan tunjangan profesi lainnya. Untuk memajukan bidang kearsipan maka para arsiparis harus didorong untuk memfokuskan diri dalam bidang kearsipan dengan cara meningkatkan imbalan materi dan kesejahteraan non-materi bagi mereka, termasuk pemberian bea siswa pendidikan, pemberian piagam penghargaan atas prestasi bidang kearsipan, dan lain-lain.

Peningkatan profesionalitas dan kompetensi SDM kearsipan memerlukan program pengembangan SDM kearsipan. Pentingnya pengelolaan SDM kearsipan ditekankan oleh Kurtz yang mengemukakan elemen-elemen penting yaitu seleksi, evaluasi dan profesionalisme (Michael J, 1988: 248). Tahap seleksi atau rekrutmen menekankan pentingnya minat dan ketrampilan di bidang kearsipan dari calon personil yang akan dipilih. Hasibuan menyatakan bahwa 
pengembangan adalah suatu usaha untuk meningkatkan kemampuan teknis, teoritis, konseptual dan moral karyawan sesuai dengan kebutuhan pekerjaan/ jabatan melalui proses pendidikan dan pelatihan (Hasibuan, 2007: 69). Pendidikan bertujuan meningkatkan keahlian teoritis, konseptual dan moral karyawan sedangkan pelatihan dimaksudkan untuk meningkatkan ketrampilan teknis pelaksanaan pekerjaan karyawan.

Program pengembangan diperlukan untuk mengarahkan pengelola arsip untuk dapat menerapkan suatu sistem, standar atau kebijakan dalam organisasi sehingga prosedur-prosedur dapat diterapkan sesuai kondisi organisasi. Dalam melaksanakan tugas pengelolaan arsip mereka harus memastikan bahwa aturan, prosedur dan praktek penanganan arsip dilakukan secara tepat dan konsisten. Untuk itu program pendidikan dan pelatihan diharapkan akan dapat meningkatkan pengetahuan dan ketrampilannya serta kerja sama dan bertukar pengetahuan dengan profesi bidang lain yang terkait seperti pustakawan, staf bidang teknologi informasi, dan sebagainya.

Pengembangan profesi kearsipan umumnya diberikan dalam bentuk "in-house" atau melalui kursus-kursus yang diajarkan di perguruan tinggi. Kurtz menyebutkan bahwa suatu program pengembangan profesi kearsipan yang baik harus memenuhi unsur-unsur berikut ini (Michael J, 1988: 249) 1) Pelatihan “on-the-job” mengenai teori dan praktek kearsipan dasar, yang dilengkapi dengan kursus akademis dan seminar atau workshop yang didukung oleh organisasi professional; 2) Staf yang bekerja di suatu bidang khusus dari program kearsipan secara temporer dirotasi ke bidang kearsipan lainnya sehingga dapat meningkatkan pemahaman mereka tentang khasanah arsip secara menyeluruh;

3) Arsiparis yang bertugas dalam aspek manajerial harus mendapatkan pelatihan profesional yang sistematis mengenai bidang yang menjadi tanggungjawab mereka, misalnya analisis statistik, perencanaan, penganggaran dan manajemen personal, baik yang ditawarkan oleh lembaga pemerintah, masyarakat profesional maupun institusi akademis; 4) Perlu adanya seorang kordinator untuk mengidentifikasi tawaran/ kesempatan- kesempatan pelatihan dan mengelola kegiatan pelatihan "in-house" serta penetapan rotasi staf; 5) Institusi kerasipan harus mendukung minat staf untuk melakukan penelitian yang akan dipublikasikan dalam teori dan praktek kearsipan, manajemen arsip maupun topik-topik kesejarahan, misalnya melalui bantuan dana publikasi, menyediakan waktu untuk meneliti pada jam kerja harian, dan lain-lain; 6) Manajer kearsipan juga harus mendorong staf untuk berpartisipasi dalam masyarakat/ asosiasi kearsipan di tingkat lokal, regional, nasional maupun internasional.

Di Indonesia ANRI sebagai penyelenggara dan pembina kearsipan nasional sebagaimana dijelaskan oleh Dwi mengadakan berbagai jenis diklat yakni: diklat fungsional yang terdiri dari diklat penciptaan arsiparis terampil dan arsiparis ahli, diklat teknis kearsipan yang terdiri dari (Nurmaningsih, 2009: 11): diklat manajemen arsip dinamis, diklat pengawasan, diklat tim penilai jabatan fungsional arsiparis, diklat penilaian arsip, diklat penyusunan Jadwal Retensi Arsip (JRA), diklat manajemen arsip statis, dan lain-lain, serta diklat-diklat penunjang seperti diklat beberapa bahasa asing, diklat paleografi, diklat teknologi informasi, diklat tutorial, dan lain-lain, serta diklat sertifikasi bagi SDM kearsipan yang ingin mendapatkan pengakuan formal terhadap kompetensi dan profesionalitas arsiparis dan pengelola arsip.

Selain itu ANRI juga telah mengembangkan diklat aplikasi Sistem Informasi Kearsipan Nasional (SIKN) dan aplikasi Jaringan Informasi Kearsipan Nasional), diklat pengelolaan arsip pemerintahan desa, diklat penyelenggaraan kearsipan (bagi pimpinan lembaga kearsipan dan unit 
kearsipan), diklat pengelolaan arsip perguruan tinggi, diklat pengelolaan arsip berbasis TIK, diklat program arsip vital, dan diklat layanan informasi kearsipan (Anri, 2012: 54).

\section{KESIMPULAN}

SDM kearsipan dalam kapasitasnya sebagai pimpinan maupun pelaksana pengelolaan arsip dalam bidang keahlian tertentu seperti akuisisi, pengolahan, preservasi, penilai arsip dan sebagainya, dipersyaratkan memiliki kualifikasi pemahaman, kemampuan dan pengalaman dalam bidang/kegiatan kearsipan, baik yang bersifat teoritis maupun praktis. Profesionalitas mereka dapat diperoleh melalui pendidikan formal kearsipan yang akuntabel dan profesional, atau diklat kearsipan sesuai kecakapan atau bidang-bidang khusus yang dibutuhkan. Di samping itu keterampilan manajerial juga sangat penting khususnya pada level pimpinan. ANRI terus memacu lembaganya sebagai pembina kearsipan nasional, termasuk dalam pengembangan profesionalitas SDM kearsipan dengan menyediakan program pendidikan dan pelatihan fungsional diklat teknis kearsipan maupun diklat penunjang lainnya yang diperlukan sesuai tuntutan zaman.

\section{DAFTAR PUSTAKA}

Bogdan dan Taylor, 1975 dalam J. Moleong, Lexy. 1989. Metodologi Penelitian Kualitatif. Bandung: Remadja Karya

Elizabeth, Shepherd, Developing A New Academic Discipline UCL's Contribution To The Research And Teaching Of Archives And Records Management.Aslib Proceedings: New Information Perspectives. Vol. 58 No. 1/2, 2006.

Glenda, Acland, Glossary. 1993. Dalam Judith Ellis. Keeping Archives. (2nd Ed.). Port Melbourne: Dw Thrope.

Hadari Nawawi. (1993). Metode Penelitian Bidang Sosial. Yogyakarta: Gadjah Mada University Press.

Indonesia. Arsip Nasional Republik Indonesia. 2012. Melestarikan Memori Kolektif Bangsa. Jakarta: ANRI.

Istiana, Purwani. 2014. Layanan Perpustakaan, Yogyakarta: Ombak.

Iwan M, Bambang. Arsiparis Sebagai Profesi Dan Standar Kompetensinya (Menguak Konsep Jabatan Fungsional Arsiparis). Majalah Arsip: Media Kearsipan Nasional. Edisi 51, 2009. Jakarta: ANRI.

Kistanto, Nurdien H. 2014. Etika Profesi Kearsipan. Tanggerang Selatan: Universitas Terbuka.

Malayu, Hasibuan, S.P. 2007. Manajemen Sumber Daya Manusia. Jakarta: Bumi Aksara.

Michael J, Kurtz. 1988. Archival Management. Dalam James Gregory Bradsher (Ed.). Managing archives and archival institutions. Chicago: The University of Chicago Press.

Nurmaningsih, Dwi. 2009. Pengembangan Jabatan Fungsional Arsiparis untuk Meningkatkan Profesionalisme Di Bidang Kearsipan. Jurnal Kearsipan Vol 4/ ANRI/ 12/ 2009, Jakarta: Pusat Pengkajian Dan Pengembangan Sistem Kearsipan Arsip Nasional RI. 
Suwarno, Wiji. 2010. Ilmu Perpustakaan Dan Kode Etik Pustakawan. Jogjakarta: Ar- Ruzz Media.

Schauder, Kennedy, Jay, Cherryl. 1998. Records Management A Guide To Corporate Record Keeping. South Melbourne: Addison Wesley Longman.

Society Of American Archivists (SAA). 1999. College And University Archives Section. Guidelines For College And University Archives.

Widyarsono, Sumrahyadi, Toto. 2014. Manual Kearsipan. Tanggerang Selatan: Universitas Terbuka. 